\title{
HTLV-1 bZIP factor perturbs immune response to the pathogens in vivo by inhibiting IFN-gamma production
}

\author{
Kenji Sugata', Yorifumi Satou', Jun-ichirou Yasunaga', Kisato Nosaka², Masao Matsuoka ${ }^{\text {1* }}$ \\ From 15th International Conference on Human Retroviruses: HTLV and Related Viruses \\ Leuven and Gembloux, Belgium. 5-8 June 2011
}

HTLV-1 carriers and the patients with adult T-cell leukemia (ATL) frequently suffer from the opportunistic infections. Although it has been known that HTLV1 infection evokes cell-mediated immune deficiency, its mechanism remains unknown. HTLV-1 bZIP factor (HBZ) is encoded in the minus strand of HTLV-1, which is constitutively expressed and involved in the proliferation of HTLV-1-infected cells. In this study, we investigated the role of $\mathrm{HBZ}$ in immunodeficiency in a mice model. HBZ transgenic (HBZ-Tg) mice were infected with HSV-2 and Listeria monocytogenes and evaluated for cellular immunity to those pathogens. The clearance of both pathogens was impaired in HBZ-Tg mice compared with the non-transgenic littermate. In the both infection, production of IFN-gamma in CD4+ T cells was significantly reduced in $\mathrm{HBZ}-\mathrm{Tg}$ mice. In addition, ectopic expression of HBZ in primary human $\mathrm{CD} 4+\mathrm{T}$ cells impaired IFN-gamma production in vitro. As the molecular mechanisms, we found that HBZ suppressed transcription of IFNG promoter. Our results suggest that HBZ plays a crucial role for cellular immunodeficiency in HTLV-1-infected subjects.

\section{Author details \\ 'Laboratory of Virus Control, Institute for Virus Research, Kyoto University, Kyoto, Japan. ${ }^{2}$ Department of Hematology, Kumamoto University School of} Medicine, Japan.

Published: 6 June 2011

\footnotetext{
* Correspondence: mmatsuok@virus.kyoto-u.ac.jp

'Laboratory of Virus Control, Institute for Virus Research, Kyoto University, Kyoto, Japan
}

Full list of author information is available at the end of the article
doi:10.1186/1742-4690-8-S1-A102

Cite this article as: Sugata et al.: HTLV-1 bZIP factor perturbs immune response to the pathogens in vivo by inhibiting IFN-gamma production. Retrovirology 2011 8(Suppl 1):A102.
Submit your next manuscript to BioMed Central and take full advantage of:

- Convenient online submission

- Thorough peer review

- No space constraints or color figure charges

- Immediate publication on acceptance

- Inclusion in PubMed, CAS, Scopus and Google Scholar

- Research which is freely available for redistribution

Submit your manuscript at www.biomedcentral.com/submit
Biomed Central
C Biomed Central 